DOI: $10.21802 / \mathrm{acm} .2021 .2 .5$

UDC: $616.379-008.64+616-056.52+616.12-008.318+616-092.9+546.15$

\title{
INFLUENCE OF INSULIN RESISTANCE AND OBESITY ON THE AUTONOMIC REGULATION OF RAT HEART RATE UNDER CONDITIONS OF ADEQUATE AND LIMITED IODINE SUPPLY \\ Tetiana Todoriv
}

\author{
Ivano-Frankivsk National Medical University, Ivano-Frankivsk, Ukraine
}

\begin{abstract}
Cardiovascular diseases remain a major medical problems in most countries around the world, causing significant economic disbenefit. An important pathogenetic mechanism of the influence of insulin resistance and hypothyroidism on the cardiovascular system is the alteration in the autonomic regulation of heart rhythm.

Objective. The aim of the study was to evaluate the dynamics of heart rate variability (HRV) in rats with insulin resistance and obesity under the conditions of adequate and limited iodine supply.

Materials and Methods. Studies were performed on 90 nonlinear rats pandomized by random sampling. The response of the autonomic nervous system (ANS) was studied using a computer program to analyze HRV "Poly-Spectrum.NET" with the additional module "Poly-Spectrum.NET/Veterinary".

Results. It was determined that the co-directed dynamics of geometric and statistical analysis of HRV and balance shift in the direction of the low-frequency component in spectrum analysis of the heart rate regarding control data were revealed in rats with isolated insulin resistance, obesity and combined endocrinopathy (insulin resistance and obesity under the conditions of limited iodine supply).

Conclusion. The prevalence of sympathetic ANS activity under the conditions of insulin resistance and obesity can contribute to cardiac arrhythmias, the development of diabetic autonomic neuropathy and with a high probability to cause some cases of life-threatening arrhythmias (supraventricular and ventricular). Iodine deficiency contributes to the depletion of regulatory effects of ANS and limits the range of adaptive capabilities and resources of the organism.
\end{abstract}

Key words: heart rate variability, autonomic nervous system, insulin resistance, obesity, iodine deficiency.

Problem statement and analysis of recent research. Cardiovascular diseases remain a major medical problems in most countries around the world, causing significant economic disbenefit. In Ukraine, cardiovascular pathology ranks first in the structure of mortality and disability and leads to a decrease in life expectancy at 10-12 years [1].

The circulatory system, along with traditional risk factors, is affected by comorbidities. Among the most common comorbid pathologies an insulin resistance, iodine deficiency and obesity play a very significant role [2]. An important pathogenetic mechanism of the influence of insulin resistance and hypothyroidism on the cardiovascular system is the alteration in the autonomic regulation of heart rhythm. A dangerous complication of insulin resistance is the diabetic autonomic neuropathy (DAN), which can adversely affect adaptive changes in heart rhythm. Under such conditions, the alteration in the contractile function of the heart is associated with a violation of autonomic regulation. Early diagnosis of DAN is an extremely important factor to prevent the development of lifethreatening arrhythmias against the background of diabetes mellitus [3].

The functional state of autonomic tone reflects the dynamics of heart rate variability (HRV). The study is based on the assessment of the state of neurohumoral regulation of physiological functions of the body, the characteristics of the relationship between the sympathetic and parasympathetic nervous system [4]. Analysis of HRV indices allows us to assess the severity and risks of the development of physiological disorders of the heart.

Objective.Therefore, the aim of the study was to evaluate the dynamics of HRV in rats with insulin resistance and obesity under the conditions of adequate and limited iodine supply.

\section{Material and methods}

Studies were performed on 90 nonlinear rats pandomized by random sampling. Animals were divided into the following groups: group 1 - control (intact animals, $\mathrm{n}=15$ ), group 2 - animals with insulin resistance under the conditions of proper iodine supply $(\mathrm{n}=15)$, group 3 - obese animals under the conditions of proper iodine provision $(n=15)$, group 4 - animals with hypothyroid dysfunction against the background of iodine deficiency $(n=15)$, group 5 -insulin-resistant animals under the conditions of iodine deficiency, and group 6 - animals with obesity under the conditions of iodine deficiency $(n=15)$. The control $\left(1^{\text {st }}\right)$ group included intact animals, which were kept on a standard diet, normal temperature and light regime of the vivarium.

In order to simulate insulin resistance $\left(2^{\text {nd }}\right.$ and $5^{\text {th }}$ groups), the animals received a $10 \%$ solution of fructose instead of drinking water for eight weeks [5]. Obesity was reproduced by keeping rats on a high-calorie diet 
[6]. Rats of groups 4-6 were on an iodine deficiency diet for two month [7]. The state of insulin resistance was determined by the HOMA-IR index, which was calculated according to the content of glucose and insulin in the blood serum [8]. The content of glycosylated hemoglobin was determined in the whole blood. Control over the reproduction of alimentary obesity was carried out by weighing the animals, measuring the nasal-anal length and calculating the body mass index (BMI). To determine the iodine supply condition of rats there was determined the concentration of iodine in daily portions of urine, which was collected using metabolic cages. [10].

All animals were recorded and digitized electrocardiogram in the II standard lead using a veterinary cardiograph "Poly-Spectrum 8/B". During manipulation, rats were under anesthesia (sodium thiopental, $25 \mathrm{mg} / \mathrm{kg}$ intraperitoneally) and were immobilized on their backs. The response of the autonomic nervous system was studied using a computer program to analyze heart rate variability "Poly-Spectrum.NET" with the additional module "Poly-Spectrum.NET/Veterinary". The following indices of geometric analysis of HRV were determined: mode (Mo) - the range of values of the interval R-R, which occurs most often during the studied time (in $\mathrm{ms}$ ); mode amplitude (AMo) - the relative number of $\mathrm{R}-\mathrm{R}$ cardio-intervals that fall in the same range with the mode (in \%), variation range (VR) - the difference between the largest and smallest cardio-intervals (in $\mathrm{ms}$ ). Statistical parameters of the time series of cardiointervals were evaluated according to the following data: SDNN (standard deviation of the full array of cardio-interval), RMSSD (square root of the sum of the differences of a series of cardio-intervals, which is an index of parasympathetic link activity of autonomic regulation), pNN50\% (number of pairs of the series of $\mathrm{NN}$-intervals differed by more than $50 \mathrm{~ms}$ in \%). During the study there was evaluated the spectral analysis of heart rate, which allows to quantify the different frequency characteristics of heart rate fluctuations and is based on the identification of the wave structure of heart rate, i.e. on the construction of cardio-intervals, followed by analysis of numerical series by various mathematical methods. HRV spectral analysis identifies the following main spectral components that correspond to certain physiological processes: HF power spectrum of the high-frequency component, LF - power of the spectrum of the low-frequency component, VLF - power of the heart rate spectrum in the very low frequencies, $\mathrm{LF} / \mathrm{HF}$ - centralization index. Waves in the range of $0.15-0.4 \mathrm{~Hz}-$ high frequency (HF - High Frequency), are often identified with respiratory arrhythmia and reflect the intensity of parasympathetic effects. The power of low-frequency waves in the range of $0.05-0.15 \mathrm{~Hz}$ ( $\mathrm{LF}$ - Low Frequency) is influenced by the tone of the predominantly sympathetic and partially parasympathetic division of the autonomic nervous system, as well as other factors. Waves with a very low frequency less than $0.05 \mathrm{~Hz}$ (VLF - Very Low Frequency) reflect the functioning of the neurohumoral link of regulation, suprasegmentary (central) parts of the sympathetic nervous system. The LF/HF ratio (ratio of low- and high-frequency components) was calculated as an index of the balance of the sympathetic and parasympathetic divisions of the autonomic nervous system.

\section{Results and discussion}

As a result of the performed study, the most pronounced changes in carbohydrate homeostasis were observed in animals of the groups 2 and 5 (Table 1). In particular, in rats of the group 2 there was found an increase of the serum glucose - at $43.1 \%\left(\mathrm{p}_{1-2}<0.01\right)$, insulin - at $20.9 \%\left(\mathrm{p}_{1-2}<0.001\right), \mathrm{HbA} \mathrm{c}-$ at $91.9 \%\left(\mathrm{p}_{1-2}<0.001\right)$ and HOMA-IR index - at $94.0 \%\left(\mathrm{p}_{1-2}<0.001\right)$ relative to control values. In animals of the group 5 there was an increase in the concentration of glucose - at $64.6 \%$ $\left(\mathrm{p}_{1-5}<0.01\right)$, insulin - at $54.2 \%\left(\mathrm{p}_{1-5}<0.001\right), \mathrm{HbA} 1 \mathrm{c}-$ 2.0 -fold $\left(\mathrm{p}_{1-5}<0.001\right)$ and HOMA-IR index -2.5 -fold $\left(\mathrm{p}_{1-5}<0.001\right)$ relative to data in intact animals. In rats of the experimental group 3, the concentration of glucose has increased at $33.8 \%\left(\mathrm{p}_{1-3}<0.01\right)$, insulin - at $20.8 \%$ $\left(\mathrm{p}_{1-3}<0.01\right), \mathrm{HbA1c}-$ at $35.6\left(\mathrm{p}_{1-3}<0.05\right)$ and HOMAIR index $-64.1 \%\left(\mathrm{p}_{1-3}<0.01\right)$ relative to control data. Indices of carbohydrate metabolism in rats on an iodine deficiency diet, did not differ significantly from the control group data.

During the experiment in animals, the most significant changes in BMI were observed in animals of the group 3 - an increase at $52.17 \%\left(\mathrm{p}_{1-3}<0.01\right)$ and the group 6 - an increase at $71.74 \%\left(\mathrm{p}_{1-6}<0.01\right)$ regarding the control data.

As a result of the study in insulin resistance, a decrease in thyroid homeostasis, in particular $\mathrm{fT}_{3}$ and $\mathrm{fT}_{4}$ at 18.99 $\left(\mathrm{p}_{1-2}<0.05\right)$ and $13.06 \%\left(\mathrm{p}_{1-2}<0.05\right)$ relative to control values was observed. In animals' obesity it was revealed an increase of TSH at $23.08 \%\left(\mathrm{p}_{1-3}<0.05\right)$ in blood serum relative to values in intact animals. In rats of groups 4-6 alterations in thyroid homeostasis were the most significant and reflected the development of hypothyroid dysfunction (Table 2). In iodine deficiency in animals there was a decrease in $\mathrm{fT}_{3}$ and $\mathrm{fT}_{4}$ at 35.11 and $37.02 \%$ $\left(\mathrm{p}_{1-4}<0.001\right)$ against the background of an increase of TSH at $53.85 \%\left(\mathrm{p}_{1-4}<0.001\right), \mathrm{fT}_{3} / \mathrm{fT}_{4}-$ at $18.18 \%\left(\mathrm{p}_{1-4}<0.05\right)$ and $\mathrm{TSH} / \mathrm{fT}_{4}-2.2$-fold $\left(\mathrm{p}_{1-4}<0.001\right)$ relative to control. In rats with combined endocrinopathy of the groups 5 and 6 , changes in thyroid status were even more pronounced. In particular, there was found a decrease in $\mathrm{fT}_{3}$ and $\mathrm{fT}_{4}$ at $64.13\left(\mathrm{p}_{1-5}<0.001\right)$ and $58.28 \%\left(\mathrm{p}_{1-6}<0.001\right)$ and 28.27 $\left(\mathrm{p}_{1-5}<0.001\right)$ and $23.92 \%\left(\mathrm{p}_{1-6}<0.01\right)$, an increase of TSH at $30.77\left(\mathrm{p}_{1-5}<0.01\right)$ and $61.53 \%\left(\mathrm{p}_{1-6}<0.001\right), \mathrm{TSH} / \mathrm{fT}_{4}$ - twice $\left(\mathrm{p}_{1-5}<0.05\right)$ and 2.4-fold $\left(\mathrm{p}_{1-6}<0.001\right)$ relative to data in intact animals. 
Table 1. Indexes of thyroid status in rats with insulin resistance, obesity, iodine deficiency and their combination $(\mathbf{M} \pm \mathbf{m} ; \mathbf{n}=\mathbf{1 5})$

\begin{tabular}{|c|c|c|c|c|c|c|}
\hline Groups of animals & $\mathrm{fT}_{3}, \mathrm{pmol} / \mathrm{l}$ & $\mathrm{fT}_{4}, \mathrm{pmol} / \mathrm{l}$ & TSH, mIU/1 & $\mathrm{fT}_{3} / \mathrm{fT}_{4}$, & $\mathrm{TT} / \mathrm{fT}_{4}$, & $\begin{array}{c}\text { Iodine in urine, } \\
\mathrm{mcg} / \mathrm{l}\end{array}$ \\
\hline $\begin{array}{l}1^{\text {st }} \text { control } \\
\text { (intact animals) }\end{array}$ & $6.58 \pm 0.30$ & $28.93 \pm 1.04$ & $0.13 \pm 0.01$ & $0.22 \pm 0.01$ & $0.005 \pm 0.001$ & $103.24 \pm 4.01$ \\
\hline $\begin{array}{l}2^{\text {nd }} \text {-га experimental } \\
\text { (animals with } \\
\text { insulin resistance ) }\end{array}$ & $\begin{array}{c}5.33 \pm 0.37 \\
p_{1-2}<0.05\end{array}$ & $\begin{array}{c}25.15 \pm 1.24 \\
\mathrm{p}_{1-2}<0.05\end{array}$ & $0.10 \pm 0.02$ & $0.20 \pm 0.01$ & $0.004 \pm 0.001$ & $94.63 \pm 3.31$ \\
\hline $\begin{array}{l}3^{\text {rd }} \text { experimental } \\
\text { (animals with } \\
\text { obesity) }\end{array}$ & $\begin{array}{c}6.96 \pm 0.47 \\
p_{2-3}<0.05\end{array}$ & $29.33 \pm 1.62$ & $\begin{array}{c}0.16 \pm 0.009 \\
\mathrm{p}_{1-3}<0.05 \\
\mathrm{p}_{2-3}<0.05\end{array}$ & $\begin{array}{c}0.24 \pm 0.07 \\
\mathrm{p}_{2-3}<0.05\end{array}$ & $0.007 \pm 0.001$ & $\begin{array}{c}92.62 \pm 2.98 \\
\mathrm{p}_{1-3}<0.05\end{array}$ \\
\hline $\begin{array}{l}4^{\text {th }} \text { experimental } \\
\text { (iodine deficiency } \\
\text { animals) }\end{array}$ & $\begin{array}{c}4.27 \pm 0.33 \\
\mathrm{p}_{1-4}<0.001 \\
\mathrm{p}_{2-4}<0.05 \\
\mathrm{p}_{3-4}<0.05\end{array}$ & $\begin{array}{c}18.22 \pm 1.74 \\
\mathrm{p}_{1-4}<0.001 \\
\mathrm{p}_{2-4}<0.01 \\
\mathrm{p}_{3-4}<0.001\end{array}$ & $\begin{array}{l}0.20 \pm 0.01 \\
\mathrm{p}_{1-4}<0.001 \\
\mathrm{p}_{2-4}<0.001 \\
\mathrm{p}_{3-4}<0.01\end{array}$ & $\begin{array}{l}0.26 \pm 0.01 \\
\mathrm{p}_{1-4}<0.05 \\
\mathrm{p}_{2-4}<0.001\end{array}$ & $\begin{array}{c}0.011 \pm 0.001 \\
\mathrm{p}_{1-4}<0.001 \\
\mathrm{p}_{2-4}<0.001 \\
\mathrm{p}_{3-4}<0.05\end{array}$ & $\begin{array}{l}52.65 \pm 6.58 \\
\mathrm{p}_{1-4}<0.001 \\
\mathrm{p}_{2-4}<0.001 \\
\mathrm{p}_{3-4}<0.001\end{array}$ \\
\hline $\begin{array}{l}5^{\text {th }} \text { experimental } \\
\text { (insulin-resistant } \\
\text { animals under } \\
\text { conditions of iodine } \\
\text { deficiency) }\end{array}$ & $\begin{array}{c}2.36 \pm 0.38 \\
\mathrm{p}_{1-5}<0.001 \\
\mathrm{p}_{2-5}<0.001 \\
\mathrm{p}_{3-5}<0.001 \\
\mathrm{p}_{4-5}<0.01\end{array}$ & $\begin{array}{l}13.17 \pm 2.29 \\
\mathrm{p}_{1-5}<0.001 \\
\mathrm{p}_{2-5}<0.001 \\
\mathrm{p}_{3-5}<0.001\end{array}$ & $\begin{array}{c}0.17 \pm 0.009 \\
\mathrm{p}_{1-5}<0.01 \\
\mathrm{p}_{2-5}<0.01 \\
\mathrm{p}_{4-5}<0.01\end{array}$ & $\begin{array}{c}0.18 \pm 0.01 \\
\mathrm{p}_{1-5}<0.05 \\
\mathrm{p}_{3-5}<0.001 \\
\mathrm{p}_{4-5}<0.001\end{array}$ & $\begin{array}{c}0.010 \pm 0.002 \\
\mathrm{p}_{1-5}<0.05 \\
\mathrm{p}_{2-5}<0.05\end{array}$ & $\begin{aligned} 61.68 \pm 6.45 \\
\mathrm{p}_{1-5}<0.001 \\
\mathrm{p}_{2-5}<0.001 \\
\mathrm{p}_{3-5}<0.001\end{aligned}$ \\
\hline $\begin{array}{l}6^{\text {th }} \text { experimental } \\
\text { (animals with } \\
\text { obesity under } \\
\text { conditions of iodine } \\
\text { deficiency) }\end{array}$ & $\begin{array}{l}4.72 \pm 0.30 \\
p_{1-6}<0.001 \\
p_{5-6}<0.001\end{array}$ & $\begin{array}{c}22.01 \pm 1.85 \\
\mathrm{p}_{1-6}<0.01 \\
\mathrm{p}_{3-4}<0.01 \\
\mathrm{p}_{5-6}<0.01\end{array}$ & $\begin{array}{l}0.21 \pm 0.02 \\
\mathrm{p}_{1-6}<0.01 \\
\mathrm{p}_{2-6}<0.01 \\
\mathrm{p}_{3-6}<0.05\end{array}$ & $\begin{array}{c}0.25 \pm 0.01 \\
\mathrm{p}_{2-5}<0.01 \\
\mathrm{p}_{5-6}<0.001\end{array}$ & $\begin{array}{c}0.012 \pm 0.75 \\
\mathrm{p}_{1-6}<0.01 \\
\mathrm{p}_{2-6}<0.01 \\
\mathrm{p}_{3-6}<0.05\end{array}$ & $\begin{array}{l}65.20 \pm 5.62 \\
\mathrm{p}_{1-6}<0.001 \\
\mathrm{p}_{2-6}<0.001 \\
\mathrm{p}_{3-6}<0.001\end{array}$ \\
\hline
\end{tabular}

Note: Here and in the following tables: $\mathrm{P}-$ a reliable difference between the indexes experimental groups

The results of the performed experiment showed that against the background of insulin resistance and iodine deficiency there were changes in the geometric, static and spectral parameters of HRV (Table 3).

In rats with insulin resistance after the eighth week of the experiment, changes in the geometric and statistical analysis of HRV were observed, in particular, a decrease in Mo at $16.9 \%\left(\mathrm{p}_{1-2}<0.05\right)$, $\mathrm{BP}-$ at $22.9 \%\left(\mathrm{p}_{1-2}<0.05\right)$, and an increase in AMo at $34.6 \%\left(\mathrm{p}_{1-2}<0.01\right)$ relative to data in intact animals. Such alterations occurred against the background of a decrease in SDNN - at $40.7 \%\left(\mathrm{p}_{1-2}<0.05\right)$ relative to control. Such dynamics of the integral index of the general assessment of existence of wave structure of a sinus heart rhythm testifies to strengthening of sympathetic activity and weakening of vagus effects. A decrease in rMSSD at $41.4 \%\left(\mathrm{p}_{1-2}<0.01\right)$ characterizes the inhibition of the activity of the parasympathetic nervous system, and a change in pNN 50\% (decrease at 55.6\%, $\mathrm{p}_{1-2}<0.05$ ) confirms the sympatho-vagal imbalance in the insulin resistance. In order to assess changes in the central regulation of heart rate, spectral parameters were evaluated, where an increase in LF (at 23.6\%, $\mathrm{p}_{1-2}<0.05$ ), LF (\%) (at 21.1\%, $\mathrm{p}_{1-2}<0.05$ ), $\operatorname{VLF}\left(\right.$ at $\left.17.2 \%, \mathrm{p}_{1-2}<0.05\right), \mathrm{LF} / \mathrm{HF}$ (2.5-fold, $\mathrm{p}_{1-2}<0.01$ ) and a decrease in $\mathrm{HF}$ (at $47.2 \%, \mathrm{p}_{1-2}<0.01$ ), $\mathrm{HF}(\%)$ (at $46.5 \%$ $\left.\mathrm{p}_{1-2}<0.001\right)$ relative to data in animals of the control group.

In obese rats, the results of HRV analysis showed changes in the following indices: a decrease in Mo at $14.7 \%\left(\mathrm{p}_{1-3}<0.05\right), \mathrm{BP}-$ at $18.1 \%\left(\mathrm{p}_{1-3}<0.05\right), \mathrm{SDNN}-$ at $33.3 \%\left(\mathrm{p}_{1-3}<0.05\right), \mathrm{rMSSD}-$ at $34.5 \%\left(\mathrm{p}_{1-3}<0.05\right)$, $\mathrm{pNN}$ $50 \%$ - at $48.8 \%\left(\mathrm{p}_{1-3}<0.05\right), \mathrm{HF}$ (at $\left.40.6 \%, \mathrm{p}_{1-3}<0.05\right), \mathrm{HF}$ (\%) (at 39.3\%, $\mathrm{p}_{1-3}<0.001$ ) relative to the control group (Table 3). A significant decrease in SDNN in animals of this group characterizes the state of autonomic dysregulation in general. Attention is drawn to the decrease in rMSSD and pNN50, which reflects the suppression of parasympathetic effects on the heart rate. Increase in AMo at $24.7 \%\left(\mathrm{p}_{1-3}<0.05\right)$, spectral indices LF (at 19.2\%, $\mathrm{p}_{1-3}<0.05$ ), LF (\%) (at 17.8\%, $\mathrm{p}_{1-3}<0.05$ ), VLF (at $16.1 \%, \mathrm{p}_{1-3}<0.05$ ) and the balance coefficient of the sympathetic and parasympathetic components of the autonomic spectrum, which reflects a significant shift of the spectrum towards sympathicotonia (LF/HF increase 2.1-fold, $\mathrm{p}_{1-3}<0.05$ ).

Analysis of the results obtained in animals under the conditions of mono iodine deficiency reflects an increase in the activity of parasympathetic HRV indices, in particular, an increase in Mo at $20.4 \%\left(\mathrm{p}_{1-4}<0.05\right), \mathrm{BP}-$ at $39.3 \%$ $\left(\mathrm{p}_{1-4}<0.01\right), \mathrm{SDNN}-$ at $55.5 \%$ (p1-4<0.01), rMSSD at $41.4 \%\left(\mathrm{p}_{1-4}<0.05\right), \mathrm{pNN} 50 \%$ - at $41.3 \%\left(\mathrm{p}_{1-4}<0.05\right)$ and a decrease in AMo at $40.1 \%\left(\mathrm{p}_{1-4}<0.001\right)$ relative to the control group. When evaluating the spectral parameters, there was a tendency to activation of the ANS due to the parasympathetic part, in particular an increase in HF (at 27.4.\% $\mathrm{p}_{1-4}<0.05$ ), HF (\%) (at 31.7\% $\mathrm{p}_{1-4}<0.05$ ) and a decrease in LF (at $27.25 \%, \mathrm{p}_{1-4}<0.01$ ), LF (\%) (at 14.4\% $\mathrm{p}_{1-4}<0.05$ ), VLF (at $21.9 \% \mathrm{p}_{1-4}<0.01$ ), $\mathrm{LF} / \mathrm{HF}$ (in $60.2 \%, \mathrm{p}_{1-4}<0.05$ ) relative to data in intact 
Tetiana Todoriv «Influence of Insulin Resistance and Obesity on the Autonomic Regulation...»

Table 2. Indexes of carbohydrate metabolism in rats with insulin resistance, obesity, iodine deficiency and their combination $(M \pm m ; n=15)$

\begin{tabular}{|c|c|c|c|c|}
\hline Groups of animals & $\begin{array}{l}\text { Insulin, } \\
\mathrm{mkOD} / 1\end{array}$ & $\begin{array}{l}\text { Glucose, } \\
\mathrm{mmol} / 1\end{array}$ & $\begin{array}{c}\text { Glycosylat } \\
\text { ed } \mathrm{Hb}, \\
\mu \mathrm{mol} \text { of } \\
\text { fructose } / \mathrm{g} \\
\mathrm{Hb}\end{array}$ & $\begin{array}{l}\text { HOMA-IR } \\
\text { index }\end{array}$ \\
\hline $\begin{array}{l}1^{\text {st }} \text { control (intact } \\
\text { animals) }\end{array}$ & $13.09 \pm 0.53$ & $4.32 \pm 0.40$ & $3.59 \pm 0.42$ & $2.51 \pm 0.28$ \\
\hline $\begin{array}{l}2^{\text {nd }}-\text { га experimental } \\
\text { (animals with insulin } \\
\text { resistance ) }\end{array}$ & $\begin{array}{l}17.71 \pm 0.52 \\
\mathrm{p}_{1-2}<0.001\end{array}$ & $\begin{array}{c}6.18 \pm 0.41 \\
\mathrm{p}_{1-2}<0.01\end{array}$ & $\begin{array}{l}6.89 \pm 0.47 \\
\mathrm{p}_{1-2}<0.001\end{array}$ & $\begin{array}{l}4.87 \pm 0.35 \\
\mathrm{p}_{1-2}<0.001\end{array}$ \\
\hline $\begin{array}{l}3^{\text {rd }} \text { experimental } \\
\text { (animals with obesity) }\end{array}$ & $\begin{array}{c}15.82 \pm 0.72 \\
\mathrm{p}_{1-3}<0.01 \\
\mathrm{p}_{2-3}<0.05\end{array}$ & $\begin{array}{l}5.78 \pm 0.28 \\
\mathrm{p}_{1-3}<0.01\end{array}$ & $\begin{array}{l}4.87 \pm 0.39 \\
\mathrm{p}_{1-3}<0.05 \\
\mathrm{p}_{2-3}<0.01\end{array}$ & $\begin{array}{l}4.12 \pm 0.37 \\
\mathrm{p}_{1-3}<0.01\end{array}$ \\
\hline $\begin{array}{l}4^{\text {th }} \text { experimental } \\
\text { (iodine deficiency } \\
\text { animals) }\end{array}$ & $\begin{array}{c}13.41 \pm 0.75 \\
\mathrm{p}_{2-4}<0.001 \\
\mathrm{p}_{3-4}<0.05\end{array}$ & $\begin{array}{l}4.28 \pm 0.44 \\
\mathrm{p}_{2-4}<0.01 \\
\mathrm{p}_{3-4}<0.05\end{array}$ & $\begin{array}{l}4.23 \pm 0.92 \\
\mathrm{p}_{2-4}<0.05\end{array}$ & $\begin{array}{c}2.55 \pm 0.29 \\
\mathrm{p}_{2-4}<0.001 \\
\mathrm{p}_{3-4}<0.01\end{array}$ \\
\hline $\begin{array}{l}5^{\text {th }} \text { experimental } \\
\text { (insulin-resistant } \\
\text { animals under } \\
\text { conditions of iodine } \\
\text { deficiency) }\end{array}$ & $\begin{array}{l}20.18 \pm 1.05 \\
\mathrm{p}_{1-5}<0.001 \\
\mathrm{p}_{3-5}<0.01 \\
\mathrm{p}_{4-5}<0.001\end{array}$ & $\begin{array}{l}7.11 \pm 0.30 \\
\mathrm{p}_{1-5}<0.001 \\
\mathrm{p}_{3-5}<0.01 \\
\mathrm{p}_{4-5}<0.001\end{array}$ & $\begin{array}{l}7.36 \pm 0.82 \\
\mathrm{p}_{1-5}<0.001 \\
\mathrm{p}_{3-5}<0.05 \\
\mathrm{p}_{4-5}<0.05\end{array}$ & $\begin{array}{l}6.37 \pm 0.53 \\
\mathrm{p}_{1-5}<0.001 \\
\mathrm{p}_{2-5}<0.05 \\
\mathrm{p}_{3-5}<0.01 \\
\mathrm{p}_{4-5}<0.001\end{array}$ \\
\hline $\begin{array}{l}6^{\text {th }} \text { experimental } \\
\text { (animals with obesity } \\
\text { under conditions of } \\
\text { iodine deficiency) }\end{array}$ & $\begin{array}{c}16.01 \pm 0.81 \\
\mathrm{p}_{1-6}<0.01 \\
\mathrm{p}_{4-6}<0.05 \\
\mathrm{p}_{5-6}<0.01\end{array}$ & $\begin{array}{l}6.72 \pm 0.36 \\
\mathrm{p}_{1-6}<0.001 \\
\mathrm{p}_{4-6}<0.001\end{array}$ & $\begin{array}{c}5.12 \pm 0.56 \\
\mathrm{p}_{1-6}<0.001 \\
\mathrm{p}_{2-6}<0.05 \\
\mathrm{p}_{5-6}<0.05\end{array}$ & $\begin{array}{c}4.79 \pm 0.25 \\
\mathrm{p}_{1-6}<0.001 \\
\mathrm{p}_{4-6}<0.001 \\
\mathrm{p}_{5-6}<0.01\end{array}$ \\
\hline
\end{tabular}

animals.

The development of insulin resistance under the conditions of limited iodine supply has led to changes in the dynamics ofHRV. Thus, in animals of the experimental group 5 there was a decrease in parasympathetic activity compared with the control group, which is confirmed by a decrease in Mo at $14.2 \%\left(\mathrm{p}_{1-5}<0.05\right), \mathrm{BP}-$ at $21.2 \%$ $\left(\mathrm{p}_{1-5}<0.05\right), \mathrm{SDNN}-$ at $29.6 \%\left(\mathrm{p}_{1-5}<0.05\right), \mathrm{rMSSD}-$ at $27.6 \%\left(\mathrm{p}_{1-5}<0.05\right)$, pNN 50\% - at 41.9\% $\left(\mathrm{p}_{1-5}<0.05\right)$, as well as spectral indices - HF (at $42.1 \%, \mathrm{p}_{1-5}<0.01$ ), HF $(\%)$ (at 38.1\%, $\left.\mathrm{p}_{1-5}<0.001\right)$. A marked decrease in SDNN less than $50 \mathrm{~ms}$ indicates a high risk of cardiovascular complications and sudden death [11]. Increase in AMo at $20.7 \%\left(\mathrm{p}_{1-5}<0.05\right)$ and spectral indices of LF (at 19.1\%, $\left.\mathrm{p}_{1-5}<0.05\right), \mathrm{LF}(\%)\left(\right.$ at $\left.17.3 \%, \mathrm{p}_{1-5}<0.05\right), \mathrm{VLF}$ (at 15.1\%, $\left.\mathrm{p}_{1-5}<0.05\right), \mathrm{LF} / \mathrm{HF}\left(2.2\right.$-fold, $\left.\mathrm{p}_{1-5}<0.05\right)$ characterize the activation of sympathetic part of the ANS.

In rats of the group 5, the studied parameters differed significantly from the data under the conditions of isolated iodine deficiency, in particular, an increase in AMo - twice $\left(\mathrm{p}_{4-5}<0.001\right), \mathrm{LF}-$ at $63,7 \%\left(\mathrm{p}_{4-5}<0,001\right)$, LF $(\%)-$ at $36,9 \%\left(\mathrm{p}_{4-5}<0.001\right)$, and sympathetic-vagal index $\mathrm{LF} / \mathrm{HF}$ index -5.5 -fold $\left(\mathrm{p}_{4-5}<0.01\right)$. A decrease in Mo at $28.7 \%\left(\mathrm{p}_{4-5}<0.001\right), \mathrm{BP}-$ at $43.5 \%\left(\mathrm{P}_{4-5}<0.01\right)$, SDNN - at 54.7\% $\left(\mathrm{P}_{4-5}<0.001\right)$, rMSSD - at $48.8 \%$ $\left(\mathrm{P}_{4-5}<0.001\right)$, pNN 50\% - at 59.0\% $(\mathrm{P}<0.05), \mathrm{HF}-$ at $54,5 \%\left(\mathrm{p}_{4-5}<0.001\right), \mathrm{HF}(\%)-$ at $52,9 \%\left(\mathrm{p}_{4-5}<0.001\right)$ regarding the data in animals with iodine deficiency.

Changes in geometric and statistical analysis were found in obese animals on an iodine deficiency diet. In particular, a decrease in Mo at $12.7 \%\left(\mathrm{p}_{1-6}<0.05\right), \mathrm{BP}-$ at $16.3 \%\left(\mathrm{p}_{1-6}<0.05\right)$, SDNN at $26.8 \%\left(\mathrm{p}_{1-6}<0.05\right), \mathrm{rMSSD}$ - at $24.1 \%\left(\mathrm{p}_{1-6}<0.05\right), \mathrm{pNN}$ $50 \%$ - at $40.6 \%\left(\mathrm{p}_{1-6}<0.05\right)$, HF (at 35.4\%, $\mathrm{p}_{1-6}<0.05$ ), HF (\%) (at 29.9\%, $\mathrm{p}_{1-6}<0.01$ ) and an increase in AMo at $20.1 \%$ $\left(\mathrm{p}_{1-6}<0.05\right)$ relative to the data control group. Such alterations indicate an increase in the influence of the sympathetic link of the ANS on the heart rhythm. At the same time, the spectral indices increased: LF (at 17.1\%, $\mathrm{p}_{1-6}<0.05$ ), LF (\%) (at 13.6\%, $\mathrm{p}_{1-6}<0.05$ ), VLF (at 13.1\%, $\mathrm{p}_{1-6}<0.05$ ), $\mathrm{LF} / \mathrm{HF}$ (at $93.5 \%, \mathrm{p}_{1-6}<0.05$ ) relative to the data in intact animals. Disorder of the balance between the links of the ANS leads to a decrease in the functional reserves of the cardiovascular system, contributing to the deterioration of coronary circulation.

In rats of the experimental group 6, HRV values differed significantly from the data under the conditions of isolated iodine deficiency, in particular, an increase of the indices of AMo - twice $\left(\mathrm{p}_{4-6}<0.001\right), \mathrm{LF}-$ at $61,0 \%$ $\left(\mathrm{p}_{4-6}<0.001\right)$, LF $(\%)-$ на 32,6\% $\left(\mathrm{p}_{4-6}<0.001\right)$, and sympathetic-vagal index $\mathrm{LF} / \mathrm{HF}-4.9$-fold $\left(\mathrm{p}_{4-6}<0.001\right)$. There was a decrease in Mo at 27.5\% $\left(\mathrm{p}_{4-6}<0.001\right)$, BP - at $40.0 \%\left(\mathrm{p}_{4-6}<0.01\right), \mathrm{SDNN}-$ at $52.4 \%\left(\mathrm{p}_{4-6}<0.001\right)$, rMSSD - at $46.4 \%\left(\mathrm{p}_{4-6}<0.001\right), \mathrm{pNN} \mathrm{50 \%} \mathrm{-} \mathrm{at} \mathrm{58.1 \%}$ $\left(\mathrm{p}_{4-6}<0.001\right), \mathrm{HF}-$ на $49,3 \%\left(\mathrm{p}_{4-6}<0.001\right), \mathrm{HF}(\%)-$ на $46,8 \%\left(\mathrm{p}_{4-6}<0.001\right)$ relative to data under the conditions of mono iodine deficiency. In combined endocrinopathy, a characteristic imbalance of the autonomic nervous system with a predominance of sympathetic regulation over parasympathetic one was revealed.

\section{Conclusion}

Decreased parasympathetic activity was observed in rats with insulin resistance and obesity with adequate and limited iodine supply compared to the data of intact animals. Such changes are confirmed by the co-directed dynamics of geometric and statistical analysis of HRV and the shift of the balance towards the low-frequency component that reflects sympathicotonia relative to 
Table 3. Changes in heart rate variability with insulin resistance and obesity under conditions of adequate iodine supply and iodine deficiency $(M \pm m, n=15)$

\begin{tabular}{|c|c|c|c|c|c|c|}
\hline Indicator & $\begin{array}{c}1^{\text {st }} \text { control (intact } \\
\text { animals) }\end{array}$ & $\begin{array}{c}2^{\text {nd }} \text {-га } \\
\text { experimental } \\
\text { (animals with } \\
\text { insulin resistance ) }\end{array}$ & $\begin{array}{c}3^{\text {rd }} \text { experimental } \\
\text { (animals with } \\
\text { obesity) }\end{array}$ & $\begin{array}{c}4^{\text {th }} \text { experimental } \\
\text { (iodine } \\
\text { deficiency } \\
\text { animals) }\end{array}$ & $\begin{array}{c}5^{\text {th }} \text { experimental } \\
\text { (insulin-resistant } \\
\text { animals under } \\
\text { conditions of } \\
\text { iodine deficiency) }\end{array}$ & $\begin{array}{c}6^{\text {th }} \text { experimental } \\
\text { (animals with } \\
\text { obesity under } \\
\text { conditions of } \\
\text { iodine deficiency) }\end{array}$ \\
\hline Mo, Mc & $142.02 \pm 0.0058$ & $\begin{array}{c}118.02 \pm 0.0052 \\
\mathrm{p}_{1-2}<0.05\end{array}$ & $\begin{array}{c}120.29 \pm 0.0072 \\
\mathrm{p}_{1-3}<0.05\end{array}$ & $\begin{array}{c}170.99 \pm 0.0074 \\
\mathrm{p}_{1-4}<0.05 \\
\mathrm{p}_{2-4}<0.001 \\
\mathrm{p}_{3-4}<0.001\end{array}$ & $\begin{array}{c}121.85 \pm 0.0068 \\
\mathrm{p}_{1-5}<0.05 \\
\mathrm{p}_{4-5}<0.001\end{array}$ & $\begin{array}{c}123.98 \pm 0.0057 \\
\mathrm{p}_{1-6}<0.05 \\
\mathrm{p}_{4-6}<0.001\end{array}$ \\
\hline AMo, $\%$ & $32.42 \pm 2.12$ & $\begin{array}{c}43.64 \pm 2.72 \\
P_{1-2}<0.01\end{array}$ & $\begin{array}{c}40.43 \pm 2.38 \\
\mathrm{P}_{1-3}<0.05\end{array}$ & $\begin{array}{l}19.42 \pm 2.32 \\
\mathrm{P}_{1-4}<0.001 \\
\mathrm{P}_{2-4}<0.001 \\
\mathrm{P}_{3-4}<0.001\end{array}$ & $\begin{array}{c}39.13 \pm 2.18 \\
\mathrm{P}_{1-5}<0.05 \\
\mathrm{p}_{4-5}<0.001\end{array}$ & $\begin{array}{c}38.93 \pm 2.08 \\
\mathrm{p}_{1-6}<0.05 \\
\mathrm{p}_{4-6}<0.001\end{array}$ \\
\hline ВР, мс & $6.12 \pm 0.45$ & $\begin{array}{l}4.72 \pm 0.48 \\
\mathrm{p}_{1-2}<0.05\end{array}$ & $\begin{array}{c}5.01 \pm 0.26 \\
\mathrm{p}_{1-3}<0.05\end{array}$ & $\begin{array}{c}8.53 \pm 0.56 \\
\mathrm{p}_{1-4}<0.01 \\
\mathrm{p}_{2-4}<0.001 \\
\mathrm{p}_{3-4}<0.001\end{array}$ & $\begin{array}{l}4.82 \pm 0.34 \\
\mathrm{p}_{1-5}<0.05 \\
\mathrm{p}_{4-5}<0.001\end{array}$ & $\begin{array}{c}5.12 \pm 0.12 \\
\mathrm{p}_{1-6}<0.05 \\
\mathrm{p}_{4-6}<0.001\end{array}$ \\
\hline $\begin{array}{l}\text { SDNN, } \\
\text { Mc }\end{array}$ & $27.18 \pm 3.08$ & $\begin{array}{c}16.12 \pm 3.85 \\
p_{1-2}<0.05\end{array}$ & $\begin{array}{c}18.13 \pm 2.12 \\
\mathrm{p}_{1-3}<0.05\end{array}$ & $\begin{array}{c}42.26 \pm 3.85 \\
\mathrm{p}_{1-4}<0.01 \\
\mathrm{p}_{2-4}<0.001 \\
\mathrm{p}_{3-4}<0.001\end{array}$ & $\begin{array}{c}19.13 \pm 2.14 \\
\mathrm{p}_{1-5}<0.05 \\
\mathrm{p}_{4-5}<0.001\end{array}$ & $\begin{array}{c}19.89 \pm 1.46 \\
\mathrm{p}_{1-6}<0.05 \\
\mathrm{p}_{4-6}<0.001\end{array}$ \\
\hline $\begin{array}{l}\text { rMSSD, } \\
\text { мс }\end{array}$ & $29.41 \pm 3.02$ & $\begin{array}{c}17.23 \pm 2.64 \\
p_{1-2}<0.01\end{array}$ & $\begin{array}{c}19.26 \pm 0.003 \\
p_{1-3}<0.05\end{array}$ & $\begin{array}{c}41.59 \pm 3.78 \\
\mathrm{p}_{1-4}<0.05 \\
\mathrm{p}_{2-4}<0.001 \\
\mathrm{p}_{3-4}<0.001\end{array}$ & $\begin{array}{c}21.29 \pm 2.18 \\
\mathrm{p}_{1-5}<0.05 \\
\mathrm{p}_{4-5}<0.001\end{array}$ & $\begin{array}{c}22.31 \pm 0.001 \\
\mathrm{p}_{1-6}<0.05 \\
\mathrm{p}_{4-6}<0.001\end{array}$ \\
\hline $\begin{array}{l}\mathrm{pNN} 50 \\
\%\end{array}$ & $1.60 \pm 0.27$ & $\begin{array}{c}0.71 \pm 0.21 \\
p_{1-2}<0.05\end{array}$ & $\begin{array}{c}0.82 \pm 0.20 \\
p_{1-3}<0.05\end{array}$ & $\begin{array}{l}2.27 \pm 0.15 \\
\mathrm{p}_{1-4}<0.05 \\
\mathrm{p}_{2-4}<0.001 \\
\mathrm{p}_{3-4}<0.001\end{array}$ & $\begin{array}{c}0.93 \pm 0.16 \\
\mathrm{p}_{1-5}<0.05 \\
\mathrm{p}_{4-5}<0.001\end{array}$ & $\begin{array}{c}0.95 \pm 0.14 \\
\mathrm{p}_{1-6}<0.05 \\
\mathrm{p}_{4-6}<0.001\end{array}$ \\
\hline $\mathrm{HF} \%$ & $31.19 \pm 1.82$ & $\begin{array}{c}16.68 \pm 2.88 \\
\mathrm{p}_{1-2}<0.001\end{array}$ & $\begin{array}{c}18.92 \pm 2.41 \\
\mathrm{p}_{1-3}<0.001\end{array}$ & $\begin{array}{c}41.09 \pm 3.68 \\
\mathrm{p}_{1-4}<0.05 \\
\mathrm{p}_{2-4}<0.001 \\
\mathrm{p}_{3-4}<0.001\end{array}$ & $\begin{array}{l}19.32 \pm 1.92 \\
\mathrm{p}_{1-5}<0.001 \\
\mathrm{p}_{4-5}<0.001\end{array}$ & $\begin{array}{c}21.86 \pm 2.21 \\
\mathrm{p}_{1-6}<0.01 \\
\mathrm{p}_{4-6}<0.001\end{array}$ \\
\hline $\mathrm{LF} \%$ & $68.81 \pm 4.12$ & $\begin{array}{c}83.32 \pm 4.87 \\
\mathrm{p}_{1-2}<0.05\end{array}$ & $\begin{array}{c}81.08 \pm 3.48 \\
p_{1-3}<0.05\end{array}$ & $\begin{array}{c}58.91 \pm 1.62 \\
\mathrm{P}_{1-4}<0.05 \\
\mathrm{p}_{2-4}<0.001 \\
\mathrm{p}_{3-4}<0.001\end{array}$ & $\begin{array}{c}80.68 \pm 2.78 \\
\mathrm{p}_{1-5}<0.05 \\
\mathrm{p}_{4-5}<0.001\end{array}$ & $\begin{array}{c}78.14 \pm 1.28 \\
\mathrm{p}_{1-6}<0.05 \\
\mathrm{p}_{4-6}<0.001\end{array}$ \\
\hline $\mathrm{HF}, \mathrm{Mc}^{2}$ & $341.20 \pm 41.21$ & $\begin{array}{c}180.15 \pm 31.20 \\
p_{1-2}<0.01\end{array}$ & $\begin{array}{c}202.67 \pm 40.72 \\
\mathrm{p}_{1-3}<0.05\end{array}$ & $\begin{array}{c}434.69 \pm 13.43 \\
\mathrm{P}_{1-4}<0.05 \\
\mathrm{p}_{2-4}<0.001 \\
\mathrm{p}_{3-4}<0.001\end{array}$ & $\begin{array}{c}197.55 \pm 25.44 \\
\mathrm{p}_{1-5}<0.01 \\
\mathrm{p}_{4-5}<0.001\end{array}$ & $\begin{array}{c}220.41 \pm 32.62 \\
\mathrm{p}_{1-5}<0.05 \\
\mathrm{p}_{4-5}<0.001\end{array}$ \\
\hline LF, $\mathrm{Mc}^{2}$ & $725.09 \pm 52.82$ & $\begin{array}{c}896.21 \pm 53.58 \\
p_{1-2}<0.05\end{array}$ & $\begin{array}{c}864.31 \pm 38.19 \\
\mathrm{p}_{1-3}<0.05\end{array}$ & $\begin{array}{c}527.50 \pm 34.62 \\
\mathrm{p}_{1-4}<0.01 \\
\mathrm{p}_{2-4}<0.001 \\
\mathrm{p}_{3-4}<0.001\end{array}$ & $\begin{array}{c}863.58 \pm 35.39 \\
\mathrm{p}_{1-5}<0.05 \\
\mathrm{p}_{4-5}<0.001\end{array}$ & $\begin{array}{c}849.08 \pm 23.44 \\
\mathrm{p}_{1-5}<0.05 \\
\mathrm{p}_{4-5}<0.001\end{array}$ \\
\hline VLF, $\mathrm{Mc}^{2}$ & $1244.28 \pm 72.15$ & $\begin{array}{c}1458.29 \pm 52.12 \\
p_{1-2}<0.05\end{array}$ & $\begin{array}{c}1444.61 \pm 54.23 \\
\mathrm{p}_{1-3}<0.05\end{array}$ & $\begin{array}{c}971.78 \pm 41.69 \\
\mathrm{p}_{1-4}<0.01 \\
\mathrm{p}_{2-4}<0.001 \\
\mathrm{p}_{3-4}<0.001\end{array}$ & $\begin{array}{c}1432.16 \pm 43.34 \\
\mathrm{p}_{1-5}<0.05 \\
\mathrm{p}_{4-5}<0.001\end{array}$ & $\begin{array}{c}1407.28 \pm 25.19 \\
\mathrm{p}_{1-6}<0.05 \\
\mathrm{p}_{4-6}<0.001\end{array}$ \\
\hline $\mathrm{LF} / \mathrm{HF}$ & $2.01 \pm 0.56$ & $\begin{array}{c}4.96 \pm 0.76 \\
p_{1-2}<0.01\end{array}$ & $\begin{array}{l}4.20 \pm 0.82 \\
\mathrm{p}_{1-3}<0.05\end{array}$ & $\begin{array}{l}0.80 \pm 0.09 \\
\mathrm{p}_{1-4}<0.05 \\
\mathrm{p}_{2-4}<0.001 \\
\mathrm{p}_{3-4}<0.001\end{array}$ & $\begin{array}{l}4.38 \pm 0.94 \\
\mathrm{p}_{1-5}<0.05 \\
\mathrm{p}_{4-5}<0.01\end{array}$ & $\begin{array}{l}3.89 \pm 0.66 \\
\mathrm{p}_{1-6}<0.05 \\
\mathrm{p}_{4-6}<0.001\end{array}$ \\
\hline
\end{tabular}


background data (decrease in Mo at 14.7-16.9\%, BP - at 18.1-22. 9\%, SDNN - at 33.3-40.7\%, rMSSD at $34.5-41.4 \%$, pNN $50 \%$ - at $48.8-55.6 \%$, HF - at 40.6-47. 2\%, HF (\%) - at 39.3-46.5\%. A pronounced autonomic imbalance, which is accompanied by increased parasympathetic activity on the heart, develop in animals with iodine deficiency. Iodine deficiency contributes to the depletion of regulatory effects of ANS and limits the range of adaptive capabilities and resources of the organism.

In general, the prevalence of sympathetic ANS activity under the conditions of insulin resistance and obesity can contribute to cardiac arrhythmias, the development of DAN and with a high probability to cause some cases of life-threatening arrhythmias (supraventricular and ventricular).

\section{Prospects for further research}

Complex study of the results of data on heart rate variability and metabolic imbalances that occur in conditions of insulin resistance, obesity, iodine deficiency will expand existing knowledge about the pathophysiological mechanisms of cardiovascular disease under conditions of endocrinopathies.

Ethics Policy. All experiments were carried out according to the legislation of Ukraine (Law of Ukraine №3447-IV «On protection of animals from cruel treatment», 2006), the rules of European Convention for the protection of vertebrate animals used in experimental research and for other scientific purposes (Strasbourg, 1986) and approved by the Ethics Commission of Ivano-Frankivsk National Medical University (protocol №94/17 from 16.02.2017).

Financial Disclosure. The author declared no financial support.

Conflict of Interests. The author declared that no conflict of interests existed.

\section{References}

1. Strona VI, Gorb YG, Komir IR. The variability of heart rhythm in patients with stable ischemic heart disease and diabetes mellitus type 2. Actual problems of the modern medicine: Bulletin of Ukrainian medical stomatological academy. 2018;18(4):59-64. Available from: https://doi. org/10.31718/2077-1096.18.4.59

2. Ng ACT, Delgado V, Borlaug BA, Bax JJ. Diabesity: the combined burden of obesity and diabetes on heart disease and the role of imaging. Nat Rev Cardiol. 2021 Apr;18(4):291-304. Available from: https://doi. org/10.1038/s41569-020-00465-5

3. Agashe S, Petak S. Cardiac Autonomic Neuropathy in Diabetes Mellitus. Methodist Debakey Cardiovasc J. 2018 Oct-Dec;14(4):251-256. Available from: https://doi. org/10.14797/mdcj-14-4-251

4. Catai AM, Pastre CM, Godoy MF, Silva ED, Takahashi ACM, Vanderlei LCM. Heart rate variability: are you using it properly? Standardisation checklist of procedures. Braz J Phys Ther.2020;24(2):91-102. Available from: https://doi.org/10.1016/j.bjpt.2019.02.006

5. Shuprovych AA. Porushennia metabolizmu sechovoi kysloty $\mathrm{u}$ shchuriv $\mathrm{z}$ eksperymentalnym insulinorezystentnym syndromom indykovanym fruktozoiu. Fiziol Zh. 2011; 57 (1):72-81. Available from: https://doi.org/10.15407/fz57.01.072

6. Todoriv TV.Vzayemozv'yazok pokaznykiv lipidnoho spektra, esentsial'nykh bioelementiv krovi ta masy tila pry eksperymental'nomu ozhyrinni. Eksperymental'na ta klinichna fiziolohiya i biokhimiya. 2018, 2(82): 43-48. Available from: https://doi.org/10.25040/ecpb2018.02.043

7. Hlozhyk I, Strokosh T, Voronych-Semchenko N. Microelement status in rats under iodine deficiency and insulin resistance. TEKA Archives of the Commission of Medical Sciences 2017;5(1):67-72. Available from: https:// www.pan-ol.lublin.pl/archiwum/wydawnictwa/TMed5/ Hlozhyk.pdf

8. Dunn J, Grutchfield H, Gutekunst R. Two simple methods for measuring iodine in urine. Thyroid. 1993;3:11923. Available from: https://doi.org/10.1089/thy.1993.3.119

Received: 02.11.2021

Revised: 23.11.2021

Accepted: 26.11.2021 